\title{
ETIKA DALAM PEMBANGUNAN INTERNASIONAL
}

\author{
Silsila Asri* \\ la_tansa2003@yahoo.com
}

\begin{abstract}
Inequality and poverty are the impact of the unevenness of the distribution of physical and economic development outcomes. This is the result of development which ignored the moral and ethical dimension. Liberal and neo liberal system makes the factors of production mastered by a few people that contribute to inequality. People who have little ability to access resources become increasingly poor and backward. Ethics of Third World Development emerged as a critical alternative approach theory which concern with community development or empowerment community to make their life become better. Gaoulet and others of critical alternative approach suggested at least there are three basic component which are should be conceptual foundation and practical guide in understanding the development, those are sustenance, self-esteem, and freedom.
\end{abstract}

Key Words : Ethics of Third World Development, Sustenance, Self

Esteem, Freedom

${ }^{*}$ Dosen Pada Jurusan Ilmu Hubungan Internasional Universitas Andalas 


\section{Pendahuluan}

Kajian pembangunan telah menjadi perhatian besar kalangan akademisi dan praktisi sejak lama, dan terutama setelah berakhirnya perang dunia kedua. Kajian-kajian pembangunan dalam berbagai multidisiplin ilmu (ekonomi, politik, sosiologi, psikologi, budaya, sejarah, dan lain-lain), dilakukan untuk menghasilkan sebuah kerangka teoritis dan konseptual yang diharapkan menjadi acuan bagi pelaksanaan pembangunan terutama di negaranegara yang baru merdeka dan negaranegara dunia ketiga. Akan tetapi kerangka teoritis dan konseptual tentang pembangunan yang telah dipraktekkan sepanjang sejarah hingga hari ini, bila dilihat lebih dalam pada kondisi empiris, bersifat kontraproduktif. Kontraproduktif dalam pengertian, pembangunan yang dilakukan berdasarkan konsep-konsep teoritis tersebut telah menciptkan suatu struktur masyarakat yang timpang, tidak adil, dan eksploitatif. Berbagai teori pembangunan yang muncul pun seolah-olah tak mampu mengatasi persoalan yang dihadapi masyarakat dunia. Teori-teori ekonomi sejak dari neo-klasik ekonomi konvensional sampai liberalisasi dan deregulasi juga tidak membuat bangsa-bangsa di dunia menjadi sejahtera seperti apa yang dicita-citakan.

Ketimpangan tersebut terlihat nyata dengan pembagian (stratifikasi) negara-negara di dunia, ada yang dikelompokkan dengan negara maju, negara berkembang, negara terkebelakang dan lain sebagainya. Di negeri ini, Indonesia, sendiri dapat dilihat, di belakang perumahan mewah, terdapat lingkungan kumuh yang memprihatinkan. Angka pengangguran semakin meningkat dan penyakitpenyakit kronis menular pun semakin merajalela. Lingkungan semakin terdegradasi dan tidak mampu lagi menopang keseimbangan alam. Kondisi ini membawa kita pada sebuah pertanyaan. Apa yang salah dengan praktek pembangunan? Apakah kesalahan terletak pada teori dan konsep yang menjadi acuan pembangunan atau semata karena aktor yang memperaktekkan tidak mampu melaksanakan program pembangunan sesuai dengan konsep-konsep tersebut? Dengan demikian tantangan dari studi pembangunan saat ini adalah menjembatani kesenjangan dan ketidakadilan, mempromosikan 
penanganan konflik dengan jalan yang damai, dan meningkatkan kesejahteraan masyarakat.

Sehubungan dengan berbagai kritik yang muncul, kajian-kajian mengenai pembangunan pun semakin berkembang seiring dengan kontribusi dari berbagai disiplin ilmu yang mulai mengambil pembangunan sebagai bagian dari pembahasannya. Sejumlah penstudi, terutama dari kalangan ilmuan filsafat dan etika, mengajukan pentingnya mempertimbangkan nilainilai moral dan etika dalam merumuskan konsep-konsep pembangunan. Paper ini bertujuan untuk mengulas konsep-konsep etika dan nilai-nilai moral tersebut dalam kajian pembangunan.

\section{Kerangka Teoritis Dan Konseptual Pembangunan}

Defenisi konseptual dan pendekatan yang digunakan untuk mengkaji persoalan pembagunan sangat beragam sehingga, keberhasilan pembangunan juga diukur dari seberapa besar proses pembangunan tersebut bisa memenuhi parameter yang mereka ciptakan. Akan tetapi ada sebuah kesamaan tujuan yang hendak dicapai secara umum dan sederhana dari semua kerangka teori pembangunan tersebut yakni menciptakan suatu kehidupan yang lebih baik bagi setiap orang. Kehidupan yang lebih baik bagi setiap orang tersebut tentunya memiliki standar tertentu sebagai tolak ukurnya. Sebagaimana yang dikemukakan oleh Richard Peet dan Elaine Hartwick :

" development means making a better life for everyone... a better life for most peope means, essentially, meeting basic needs: sufficient food to maintain good health; a safe, healthy place in which to live; affordable service available to everyone; and being treted with dignity and respect"

Dengan demikian parameter atau tolak ukur yang digunakan dalam melihat terpenuhinya kehidupan yang lebih baik bagi setiap orang adalah dengan terpenuhinya kebutuhankebutuhan dasar manusia. Akan tetapi dalam beberapa kajian dan pendapat para ahli yang lainnya, makna dari basic needs (kebutuhan dasar) manusia tersebut juga tidak lagi hanya merujuk pada sandang, pangan dan papan. Konsep-konsep kebebasan, keadilan, martabat, jati diri juga telah menjadi bagian dari kebutuhan dasar manusia. Pemaknaan ini memberitahu kita

${ }^{1}$ Richard Peet and Elaine Hartwick, Theories of Development, (New York : The Guilford Press, 2009), 1. 
bahwa pengertian development telah jauh berkembang dari pengertian awalnya yang semata menggunakan pendekatan ekonomi.

\section{Development as economic growth}

Pada awalnya hampir semua literatur pembangunan mengasumsikan pembangunan dalam arti meningkatkan pertumbuhan ekonomi (economic growth). Ketika pertumbuhan ekonomi terjadi maka kekayaan yang terbentuk, lambat laun akan menetes kepada masyarakat banyak. Artinya persoalan produksi lebih penting daripada distribusi (pemerataan). Pendekatan ini terutama digagaskan oleh para pemikir ekonomi tradisional (ekonomi klasik) yang mengartikan pembangunan sebagai kapasitas dari sebuah perekonomian nasional untuk menciptakan dan mempertahankan kenaikan tahuan atas pendapatan nasional bruto atau GNP (Gross National Produc) ${ }^{2}$ Berdasarkan konsep-konsep ekonomi klasik ini pembangunan lebih banyak dilihat sebagai suatu kajian ekonomi yang diukur berdasarkan tingkat kemajuan struktur produksi dan penyerapan

${ }^{2}$ Michael P. Torado, Pembangunan Ekonomi Di Dunia Ketiga, Edisi Keenam, Terj. Haris Munandar, (Jakarta : Erlangga, 1998), 18 sumber daya (employment) yang diupayakan secara terencana.

Pendekatan ekonomi, ini melihat development as economic growth. Pertumbuhan ekonomi dipercaya dapat menciptakan kesejahteraan. Menurut pemahaman ini pertumbuhan ekonomi dan masyarakat akan lebih sejahtera melalui :

1. Discovery of Riches and natural resources

Penemuan sumberdaya alam seperti gas, batu bara, minyak dan emas dapat memperomosikan pertumbuhan. Namun demikian pertumbuhan tersebut tidak akan berkelanjutan apabila pendapatan dari sumberdaya tersebut tidak ditansformasikan pada sumber-sumber pertumbuhan yang tahan lama (yang lebih berkelanjutan, sumberdaya alam ekstraktif adalah sumberdaya alam yang tidak dapat diperbaharui)

2. Effort

Bekerja lebih keras, meningkatkan jumlah jam kerja pertahun, meningkatkan partisipasi pasar tenaga kerja, memperbesar upaya dan disiplin 
3. Saving and Accumulating Capital

Bijak dalam melakukan konsumsi dengan tujuan memperbesar tabungan dan menginvestasikan tabungan ini pada barang-barang modal yang akan meningkatkan produktivitas kerja

\section{Education}

Berinvestasi di bidang pendidikan, pelatihan dan kesehatan dan hal-hal yang berkaitan dengan peningkatan produktivitas

\section{Theft}

Penyediaan sumberdaya dari masyarakat lainnya dan menggunakannya untuk mengakumulasi modal. Jika sumberdayanya tersedia tapi tidak digunakan untuk reinvestasi maka akan mengakibatkan pertumbuhan yang tidak sustainable

\section{Effeciency}

Menjadi lebih efisien dan lebih efektif dalam penggunaan modal, tenaga kerja, faktor produksi. Efektivitas merupakan hasil dari spesialisasidan perdagangan internasional, skala ekonomi, perubahan structural, dan penggunaan yang lebih baik dari kapasitas yang dimiliki.

\section{Technological Change}

Pembangunan membutuhkan ilmu pengetahuan baru mengenai bagaimana menghasilkan barang dan jasa yang bernilai tinggi yang disebut dengan teknologi. ${ }^{3}$

Tujuh komponen yang menjadi sumber dari pertumbuhan perkapita tersebut bila ditelaah lebih jauh hanya berlaku dalam sektor ekonomi dan dapat diterapkan oleh kelompok yang memiliki kemampuan modal, teknologi dan kekuasaan. Peningkatan pertumbuhan perkapita ini telah memicu negara-negara maju untuk mencuri (komponen ke-5) sumberdaya alam yang ada di negara berkembang dengan alasan pembangunan di negara tersebut. Dalam upaya akumulasi modal tersebut juga negara-negara maju yang memiliki modal dan teknologi menggalakkan investasi di negara-negara berkembang, kembali dengan alasan menyukseskan pemabangunan di negara berkembang. Masyarakat di negara berkembang tidak menjadi pemain dalam proses pembangunan tersebut melainkan menajdi buruh tenaga kerja murah dan

3 Adam Szirmai, The Dynamics of SocioEconomic Development; an Introduction, (Cambridge : Cambridge University Press, 2005), 69. 
menjadi penonton kehidupan orangorang asing yang kaya di negeri mereka sendiri.

Pembangunan yang telah dilakukan olehh berbagai negara berkembang pasca perang dunia kedua dengan berpatokan pada prinsip-prinsip ekonomi liberal ini, telah membentuk suatu struktur ekonomi dunia yang terstratafikasi dalam pembagian negara-negara maju, negara berkembang dan negara terkebelakang. Hal ini menunjukkan adanya ketimpangan dan kesenjangan. Struktur pembangunan tersebut juga telah melahirkan suatu sistem ekonomi dunia yang terliberalisasi dan munculnya era globalisasi. Globalisasi ditandai dengan integrasi, interdependensi,

dan kesalingterhubungan antarnegara bangsa. ${ }^{4}$ Globalisasi diasumsikan muncul karena kebangkitan paham neo-liberal yang sangat mengutamakan kebebasan investasi dan perdagangan. Kondisi ini sebenarnya semakin memperbesar jurang ketimpangan antara negara-negara maju dan negaranegar terkebelakang. Pembangunan negara-negara di dunia dalam

4 Budi Winarno, Pertarungan Negara vs Pasar, (Yogyakarta : Media Pressindo, 2009), 2. perspektif neo liberal harus diarahkan dalam prinsip-prinsip kebebasan ekonomi tersebut, mengeliminasi peran negara. Kondisi ini di satu sisi memang memicu munculnya motivasi untuk meningkatkan daya saing namun di sisil lain, hanya akan memperkaya kelompok yang kaya dan memiskin orang -orang yang telah miskin. Jargon-jargon globalisasi memberikan akses yang lebih luar kepada perusahaan-perusahaan multinasional untuk beroperasi di negara lain dan persoalan moral yang tidak memberikan keuntungan semakin terabaikan, karena orientasi dari sistem ekonomi ini adalah keuntungan ekonomi semata.

Pandangan ini terus berlangsung dari masa pascaperang sampai tahun 1970-an, dengan keyakinan bahwa dalam peningkatan proses produksi tersebut akan berlaku humum 'trickle down effect' yakni prinsip efek penetesan ke bawah. Prinsip ini meyakini bahwa peningkatan pertumbuhan GNP baik secara keseluruhan maupun perkapita akan menetes dengan sendirinya sehingga pada gilirannya akan menciptakan lapangan pekerjaan dan berbagai peluang ekonomi dan 
akhirnya akan menciptakan pertumbuhan ekonomi dan sosial secara merata. ${ }^{5}$ Pendekatan ini banyak menuai kritik. Pemerataan ekonomi dan sosial yang diharapkan dari prinsip tersebut tidak terbukti di lapangan. Pengalaman dasawarsa 1950-an dan 1960-an, menunjukkan ketika banyak diantara negara-negara Dunia Ketiga yang berhasil mencapai tingkat pertumbuhan ekonomi tinggi namun dalam prakteknya sebagian besar rakyatnya tetap berada di bawah garis kemiskinan.

Tidak hanya itu model pembangunan ekonomi yang dilakukan berdasarkan konsep-konsep liberal dan neo-liberal ini dalam proses pelaksanaannya juga mengabaikan nilai-nilai moral dan sosial kemasyarakatan. Pembangunan ekonomi yang dijalankan untuk melanggengkan pencapaian keuntungan ekonomi kapitalis ini tidak jarang dimulai dengan membuat kepanikan masyarakat di negara-negara berkembang. Sebagaimana yang dikemukakan dalam kajian Naomi Klien yang berjudul Shock Doctrine. Shock Doctrine, merupakan suatu

5 ibid kajian yang menceritakan bagaimana negara adidaya Amerika Serikat menyebarluaskan prinsip pasar bebas secara tidak demokratis. Prinsipprinsip penyebarluasan ide pasar bebas ternyata dilakukan dengan terlebih dahulu memabngun disorientasi masyarakat terhadap sistem perekonomian mereka, melalui krisis keuangan, provokasi kudeta, dan juga dengan invasi yang berdalih perang terhadap terorisme dan pemerintahan yang diktator. Ada sejumlah cerita sejarah yang bisa menjelaskan mengenai hal tersebut, misalnya krisis finansial di Asia tahun 1997, merupakan shock doctrine yang mengakibatkan pudarnya kepercayaan masyarakat Asia terhadap model developmental state. Invasi ke Irak merupakan cerita terbaru untuk menguasai perekonomian di Timur Tengah, yang dilakukan dengan alasan kediktatoran Saddam Husein dan teorrorisme. $^{6}$

Ada begitu banyak malapetaka kemanusiaan yang ditimbulkan dalam proses pembangunan. Sehingga persepsi sebagian orang terhadap pembangunan juga menjadi negatif.

${ }^{6}$ Naomi Klien, Shock Doctrine, diakses pada http://www.naomiklein.org/shock-doctrine 
Robert B. Potter dan kawan-kawan mencoba merangkum dan membandingkan dua interpretasi yang berbeda mengenai konsep pembangunan sebagi berikut :

Tabel 1.

\section{Alternative Interpretations of Development}

\begin{tabular}{|c|c|c|}
\hline No & Good & Bad \\
\hline 1 & $\begin{array}{l}\text { Development } \\
\text { brings economic } \\
\text { growth }\end{array}$ & $\begin{array}{l}\text { Development is a } \\
\text { dependent and } \\
\text { subordinate process }\end{array}$ \\
\hline 2 & $\begin{array}{l}\text { Development } \\
\text { brings overall } \\
\text { national progress }\end{array}$ & $\begin{array}{l}\text { Development is a } \\
\text { process creating } \\
\text { and widening } \\
\text { spatial inequalities }\end{array}$ \\
\hline 3 & $\begin{array}{l}\text { Development } \\
\text { brings } \\
\text { modernization } \\
\text { along western } \\
\text { lines }\end{array}$ & $\begin{array}{l}\text { Development } \\
\text { undermine local } \\
\text { culture and values }\end{array}$ \\
\hline 4 & $\begin{array}{l}\text { Development } \\
\text { improve the } \\
\text { provision of basic } \\
\text { needs }\end{array}$ & $\begin{array}{l}\text { Development } \\
\text { perpetuates poverty } \\
\text { and poor working } \\
\text { and living } \\
\text { conditions }\end{array}$ \\
\hline 5 & $\begin{array}{l}\text { Development can } \\
\text { help create } \\
\text { sustainable } \\
\text { growth }\end{array}$ & $\begin{array}{l}\text { Development } \\
\text { often } \\
\text { environmentally } \\
\text { unsustainable }\end{array}$ \\
\hline 6 & $\begin{array}{l}\text { Development } \\
\text { brings improved } \\
\text { governance }\end{array}$ & \begin{tabular}{l}
\multicolumn{2}{l}{ Development } \\
infringes human \\
rights and \\
undermine \\
democracy \\
\end{tabular} \\
\hline
\end{tabular}

Sumber : Robert B. Potter, J.A Tony Binns, et all, Geographies of Development, Sec. Edition, (Edinburgh: Pearson Education Limited, 2004)

Berdasarkan interpretasi buruk (bad) mengenai development di atas, dapat disimpulkan permasalahanpermasalahan yang telah terbaikan dalam proses pembangunan selama ini. permasalahan tersebut adalah, kesenjangan, subordinasi, pengabaikan nilai-nilai lokal dan budaya, kemiskinan, degradasi lingkungan dan hak asasi manusia. Konsep development Robert B. Potter, et al, dalam hal ini sudah menjadi lebih luas, dan dapat dimaknai dengan perubahan yang bersifat modernisasi. Konsep ini juga pada intinya berpijak pada pemahaman konsep-konsep ekonomi neo-liberal.

\section{Development as a Modernization}

Pembangunan sebagai proses modernisasi diartikan sebagi suatu proses untuk meniru nilai-nilai peradaban barat yang dianggap lebih maju dan beradab. Pendekatan ini kemudian berkembang menajdi suatu teori pembangunan tersendiri yang disebut teori modernisasi. Teori ini merupakan teori yang banyak dianut oleh negara-negara berkembang dan mendominasi perkembangan studi pembangunan. Teori Modernisasi berasal dari konsep-konsep dan metafora yang diturunkan dari Teori Evolusi. Perubahan sosial pada dasarnya merupakan gerakan searah, linier, progresif dan perlahan-lahan, yang membawa masyarakat berubah 
dari tahapan primitif ke tahapan yang lebih maju, dan membuat berbagai masyarakat memiliki bentuk dan struktur serupa. Teori Modernisasi melihat persoalan kemiskinan dan keterbelakangan disebabkan oleh faktor-faktor internal (misalnya manusia, nilai-nilai budaya, atau struktur sosial) yang terdapat dalam masyarakat atau negara tersebut. Faktor pendorong dan penghambat pembangunan ada di dalam negara itu sendiri. Pendidikan yang rendah atau nilai-nilai budaya yang kurang menghargai waktu misalnya dapat menjadi penyebab ketertinggalan. Maka strategi pembangunan yang dianutnya adalah memperbaiki kondisi di dalam negara tersebut, meningkatkan pendidikan, dan merubah nilai budaya yang tidak mendukung kemajuan.

Modernisasi merupakan proses bertahap. Teori Rostow misalnya, membedakan berbagai fase pertumbuhan ekonomi yang hendak dilalui oleh setiap masyarakat. Dari tatanan primitif dan sederhana menuju dan berakhir pada tatanan yang maju dan kompleks. Modernisasi sebagai proses homogenisasi. Dengan modernisasi akan terbentuk berbagai masyarakat dengan tendensi dan struktur serupa. Levy mengatakan "sesuai dengan perkembangan waktu, mereka dan kita akan semakin mirip satu sama lain...”, karena model modernisasi menjanjikan bahwa semakin modern tahapan yang telah dilalui, semakin serupa bentuk dan karakteristik berbagai masyarakat yang terlibat dalam perubahan sosial ini. Modernisasi diartikan menjadi sama dengan Barat (westernisasi).

Bagi para penganut modernisasi, modernisasi dilihat sebagai suatu perubahan progresif. Sekalipun akibat samping maupun korban modernisasi beraneka macam dan terkadang berada di luar batasbatas nilai kemanusiaan dan moral universal, dalam jangka panjang, modernisasi tidak hanya sekedar merupakan sesuatu yang pasti terjadi, tetapi modernisasi dilihat sebagai sesuatu yang diperlukan dan diinginkan. Modernisasi dilihat sebagai proses evolusioner. Modernisasi memerlukan waktu panjang, bukan perubahan revolusioner. Diperlukan waktu beberapa generasi bahkan berabad-abad untuk sampai pada tahapan akhir, dan hanya waktu dan sejarah yang dapat menyaksikan 
keseluruhan proses, hasil, dan akibat langsung mapun tidak langsung. Efek negatif dari proses modernisasi ini adalah munculnya fatalism dalam masyarakat. Tidak semua masyarakat dengan budaya dan nilai-nilai tertentu akan dengan mudah beradaptasi dengan nilai-nilai baru, apalagi apabila nilai-nilai baru tersebut diinfiltrasi secara terpaksa.

\section{Etika dalam Pembangunan}

\section{Kemiskinan}

keterbelakangan yang semakin mencolok mendorong para ekonom yang berusaha untuk merumuskan strategi baru dalam pembangunan. Pendekatan baru dalam pembangunan berusaha untuk menjembatani ketimpangan ekonomi yang diakibatkan oleh struktur ekonomi dan pembangunan ekonomi liberal. Myint sebagaimana yang dikutip oleh Adam Szirmai mengemukakan diskusi mengenai pembangunan bisa dibedakan atas dua pendekatan yakni :

\section{The fight against poverty.} Pendekatan ini memusatkan perhatian pada masalah penyebarluasan kemiskinan, kelaparan, dan kesengsaraan di negara-negara berkembang dan berusaha menjawab pertanyaan apa yang bisa dilakukan untuk memperbaiki situasi yang mmeburuk ini dalam jangka pendek

2. The analysis of long term economic and social development.

Pendekatan ini berkosentrasi pada perbandingan pembangunan di negara-negara, wilayah, dan periode sejarah yang berbeda dengan tujuan untuk mencapai pemahaman yang lebih baik mengenai faktor-faktor yang memiliki dampak jangka panjang dalam dinamika pembangunan sosial dan ekonomi. ${ }^{7}$

Berangkat dari dua perspektif ini, penulis melihat adanya sebuah peralihan dalam tradisi akademik mengenai kajian pembangunan. Kajian pembangunan tidak lagi semata hanya sebuah kajian ekonomi terapan, melainkan telah berkembang menjadi kajian yang lebih sosial. Dalam pencarian strategi baru dalam pembangunan ini, ada baiknya kita mencoba menyimak serangkaian pertanyaan yang diajukan oleh Profesor Dudley Seers mengenai konsep pembangunan sebagai berikut :

${ }^{7}$ Loc Cit, Szirmai hal. 2 


\begin{abstract}
"Pertanyaan-pertanyaan mengenai pembangunan suatu negara yang harus diajukan adalah : Apa yang terjadi dengan kemiskinan penduduk di negara itu? Bagaimana dengan tingkat penganggurannya? Apakah ada perubahan-perubahan berarti yang berlangsung atas penanggulangan masalah ketimpangan pendapatan? Jika ketiga permasalahan tersebut selama periode tertentu sedikit banyak telah teratasi, maka tidak diragukan lagi bahwa periode tersebut memang merupakan periode pembangunan bagi negara yang bersangkutan. Akan tetapi jika satu, dua atau bahkan semua dari ketiga persoalan mendasar tersebut menjadi semakin buruk, maka negara itu tidak bisa dikatakan telah mengalami proses pembangunan yang positif, meskipun barangkali selama kurun waktu tersebut pendapatan per kapitanya mengalami peningkatan hingga dua kali lipat"
\end{abstract}

Profesor Dudley Seers, dalam hal ini menegaskan bahwa, kenaikan pendapatan perkapita, tidak secara otomatis menunjukkan keberhasilan pembangunan di suatu wilayah dan kondisi ini memang telah dialami oleh beberapa negara berkembang. Pembangunan seyogyanya adalah sebuah proses yang mampu meniadakan kemiskinan dan pengangguran. Sehingga setelah tahun 1970-an wacana-wacana tentang pembangunan lebih banyak membicarakan masalah penanggulangan kemiskinan dan kesenjangan sosial akibat pembangunan ekonomi yang tidak merata. Sekarang ini, pendekatan pembangunan juga semakin lebih luas, dan berdasarkan pemahaman 'terpenuhinya kebutuhan dasar' persoalan kemiskinan dan pemerataan distribusi sumberdaya ini juga memiliki cakupan yang semakin luas yakni kebutuhan akan pelayanan dasar seperti air minum, sanitasi, kesehatan, pendidikan, tranportasi, dan kesempatan kerja. Bahkan kebutuhan dasar berkembang menjadi faktorfaktor kualitatif seperti lingkungan yang nyaman, pengambilan kebijakan yang partisipatif, dan hak-hak minoritas. Indikatornya pun bukan hanya GNP atau Indeks Gini namun indikator sosial juga berkembang dari Physical Quality of Life Index (PQLI), sampai kepada Human Development Index (HDI) yang terus dikembangkan variabelnya. Dengan demikian fenomena pembangunan tidak sematamata persoalan ekonomis atau sekedar soal pengukuran tingkat pendapatan atau tidak hanya terbatas pada masalah perhitungan masalah ketenagakerjaan.

$$
\text { Perubahan sebagai Changes }
$$
harus dimaknai sebagi suatu proses yang multidimensional yang mencakup 
perubahan-perubahan mendasar atas struktur sosial, sikap masyarakat, dan institusi-institusi nasional, disamping tetap mengejar percepatan pertumbuhan ekonomi, tetap memperhatikan penanganan ketimpangan pendapatan serta pengentasan kemiskinan. Dengan demikian hakikat pembangunan seharusnya mencerminkan perubahan total suatu masyarakat atau penyesuaian sistem sosial secara keseluruhan, tanpa mengabaikan keragama kebutuhan dasar dan keinginan individual atau kelompok masyarakat yang ada di dalamnya untuk bergerak menuju suatu kehidupan yang lebih baik. Barangkali hal inilah yang dimaknai oleh Richard Peet dengan 'a better life for everyone'.

PBB dengan UNDP-nya, World Bank, dan organsasi bantuan pembangunan internasional, negar maju dan negara berkembang kemudian berdasarkan kerangka pemikiran baru dalam pembangunan ini merumuskan suatu kerangka pembangunan millennium yang dikenal dengan Millenium Development Goals (MDGs). MDGs ini pada intinya bertujuan untuk melakukan pembangunan yang lebih humanis, tidak hanya semata ekonomi. Akan tetapi dalam kenyataannya praktekpraktek pembangunan tetap membuahkan suatu kondisi yang menyedihkan, dimana kemiskinan belum teratasi, kelaparan masih terjadi dan belakangan pelanggaran hak asasi manusia dan penhancuran lingkungan makin pesat. Jadi apa yang masih kurang dalam proses pembangunan yang dilakukan. Menurut pemikiran filsafat dan bidaya, pembangunan memerlukan sebuah etika yang menyertainya

Etika dan nilai-nilai moral harus diletakkan bersama-sama dengan pembangunan ekonomi, sosial, budaya, dan politik untuk memecahkan persoalan pembangunan. Ide pembangunan sebagai economic growth adalah nilai relatif yang cenderung berupa keuntungan dan biaya ekonomi. Maka dengan menerapkan melekatkan etika pada konsep pembanguna kita akan mampu mengklarifikasi, menilai dan memperluas pengertian tentang nilai tidak saja pada nilai ekonomi.

Studi mengenai etika pembangunan telah mengalami perkembangan pesat seiring dengan 
munculnya kritikan terhadap konsep tradisional pembangunan. Kajian etika pembangunan diawali dengan penilaian yang dilakukan para ahli dan praktisi pembangunan terhadap teori-teori dan praktek-praktek pembangunan. Pada tahun 1940-an, Gandhi di India, Prebish di Amerika Latin dan beberapa ahli di berbagai bagian dunia mengkritisi kolonialisme dan pendekatan pembangunan ekonomi. Goulet misalnya mengatakan bahwa "development needs to be redefined, demytified, and thrust into the arena of moral debate". ${ }^{8}$ Etika dan nilai harus menjadi pertanyaan dalam teori, perencanaan, dan praktek pembangunan. dalam artian, perencanaan pembangunan harus mempertimbangkan nilai-nilai kemanusiaan. Pembangunan akan kehilangan makna jika mengorbankan kemanusiaan.

Pada awal 1970-an di Amerika juga terjadi perdebatan tentang kewajiban moral bangsa atau warga dalam memberikan bantuan kepada kelompok masyarakat yang ditimpa kelaparan di negara-negara

${ }^{8}$ Goulet, Denis (1971) The Cruel Choice: A New Concept in the Theory of Development, Athenaeum, New York berkembang. Peter Singer's (1972) dengan "utilitarian argument for famine relief" dan Garrett Hardin (1974) dengan "lifeboat ethics". Hal ini didukung oleh Nigel Dower, Onora O'Neill and Jerome M. Segal pada tahun 1980-an, namun program bantuan pangan hanya satu bahagian dari solusi mengatasi kelaparan, kemiskinan, keterbelakangan, dan ketidakadilan internasional. Apa yang diperlukan menurut mereka tidak sekedar etika bantuan, namun sesuatu yang lebih komprehensif, empirik, dan relevan dengan kebijakan yaitu "Ethics of Third World Development". 9

Dalam kerangka kajian etika, pembanguna secara luas dimaknai sebagai proses perbaikan berkesinambungan atas suatu masyarakat atau suatu sistem sosial secara keseluruhan menuju kehidupan yang lebih baik atau lebih humanis. Better life ini merupakan sebuah konsep yang juga masih membutuhkan penjabaran lebih konkret. Sehingga diperlukan suatu reevaluasi terhadap perubahan sosial masyarakat akibat

\footnotetext{
9 Subhillar, Etika Pembangunan : Kajian Alternatif dalam Studi Pembangunan, diakses pada http//www.usu.ac.id/id/files/pidato/ppgb/2008/ ppgb_2008_subhilhar.pdf, 22 Januari 2010
} 
'pembangunan' secara periodik dan berkesinambungan. Gaoulet dan tokohtokoh lainnya mengatakan bahwa minimal ada tiga komponen dasar yang harus dijadikan basis konseptual dan pedoman praktis dalam memahami hakikat pembangunan yakni; kecukupan (sustenance), jati diri (selfesteem), serta kebebasan (freedom) ${ }^{10}$. Sedangkan Robert B. Potter, et al, menyatakan komponen dasar dari pembangunan itu semestinya meligkupi; people, environment, resources, institution, and communities. ${ }^{11}$ Penjelasan Goulet dan Potter pada dasarnya mengerucut pada suatu tujuan dasar yang sama yakni merencanakan suatu strategi pembangunan yang lebih manusiawi. Komponen-komponen dasar dari pembangunan tersebut saling berhubungans satu sama lainnya, sehingga akan menghasilkan pola strategi pembangunan yang beragam.

\section{a. Kecukupan (sustenance)}

Konsep sustenance dalam hal ini bukan hanya makanan, melainkan mewakili semua hal yang merupakan kebutuhan dasar manusia secara fisik.

${ }^{10}$ Loc cit. Torado, hal. 19

${ }^{11}$ Loc Cit. Potter, et al.
Kebutuhan dasar ini adalah segala sesuatu yang jika tidak dipenuhi akan menghentikan kehidupan seseorang, kondisi ini yang oleh Torado disebut sebagai 'keterbelakangan absolut'. Pembangunan ekonomi hakikatnya bertujuan untuk memenuhi kebutuhan dasar ini. Tanpa adanya keberhasilan pembangunan ekonomi secara berkesinambungan maka realiasasi pemenuhan kebutuhan manusia dan realisasi potensi manusia baik secara individu maupun masyarakat akan sulit untuk diwujudkan. Akan tetapi untuk mencapai kondisi sustenance juga diperlukan suatu cara pelaksanaan yang seharusnya tidak mengabaikan nilai-nilai sosial kemanusiaan itu sendiri. Disinilah diperlukannya standar etika tertentu. Sehingga kita akan mengenal adanya etika bisnis, etika perdagangan, etika birokrasi dan lain sebagainya.

\section{b. Jati Diri Manusia (self-esteem)}

Etika dalam segala aktivitas ekonomi untuk memenuhi kebutuhan dasar manusia tersebut ditujukan untuk pencapaian dignity (martabat) kemanusiaan yang pada akhirnya akan memenuhi komponen universal manusia yakni 'jati diri'. Jati diri ini 
merupakan sebuah penghargaan terhadap hakikat diri seorang manusia. Penghormatan terhadap jati diri ini akan mendorong munculnya motivasi untuk maju, menghargai diri sendiri, dan merasa pantas untuk melakukan atau mengejar sesuatu. Penyebaran nilai-nilai modern dalam pembangunan yang diartikans sebagai modernisasi telah mengakibatkan kejutan dan kebingungan budaya di banyak negara berkembang. Hubungan langsung dengan masyarakat lain yang secara ekonomi dan teknologi lebih maju seringkali mengakibatkan batasanbatasan nilai etika menjadi kabur. Budaya barat mengikis jati diri masyarakat di banyak negara berkembang. Banyak bangsa yang merasa dirinya kecil ketika berhadapan dengan kemajuan ekonomi dan teknologi barat, sehingga mereka berlomba-lomba untuk mengejarnya dengan melakukan modernisasi. Proses ini pun terjadi, kembali, dengan mengabaikan nilai-nilai dan etika kemanusiaan yang telah dianut secara mendalam oleh suatu masyarakat dan seringkali proses modernisasi dilakukan oleh suatu pemerintah terhadap entitas lokal dengan pemaksaan, sehingga terjadilah shock culture dan ini berimbas pada pencapaia hasil pembangunan yang negatif dan tidak maksimal.

\section{Kebebasan (freedom)}

Kebebasan dalam pembangunan harus diartikan secara luas yakni sebagai kemampuan untuk berdiri tegak sehingga tidak diperbudak oleh pengejaran aspekaspek materil dalam kehidupan ini. kebebasan juga diartikan dengan kebebasan untuk memilih pola kehidupan yang lebih sesuai dengan nilai- dan budaya yang diyakini. Tidak ada nilai universal yang semestinya harus dipaksakan pada setiap lapisan masyarakat. kebebasan dari rasa takut. Program pembangunan seringkali menghilangkan hak-hak dan rasa aman masyarakat, sehingga mereka seperti dikolonialisasi secara ekonomi. Kebebasan juga dimaknai dengan adanya ruang partisipasi yang luas bagi masyarakat dalam kegiatan pembangunan abik secara sosial, ekonomi, dan budaya. Sehingga masyarakat tidak lagi hanya sebagai penonton dan subjek penderita.

Amartya Sen yang mengadopsi Paul Streeten tentang "basic human needs" menyatakan bahwa 
pembangunan Etika Pembangunan: Kajian Alternatif dalam Studi Pembangunan bukan hanya diartikan kepada pertumbuhan ekonomi, industrialisasi, atau modernisasi, namun sebagai:

"the expansion of people's 'valuable capabilities and functionings': what people can or cannot do, e.g., whether they can live long, escape avoidable morbidity, be well nourished, be able to read and write and communicate, take part in literary and scientific pursuits, and so forth" $" 12$

Para ahli studi pembangunan sepakat bahwa dimensi moral dari teori dan praktek pembangunan merupakan komponen yang sama pentingnya dengan ilmu itu sendiri dan kebijakan yang dibuat. Pertumbuhan ekonomi sangat mungkin berakibat buruk kepada manusia, masyarakat, atau lingkungan.

\section{Kesimpulan}

Paradigma pembangunan setelah tahun 1970-an mengalami suatu perubahan yang sangat signifikan dimana, keberhasilan pembangunan tidak lagi hanya dilihat dalam kerangka parameter ekonomi (pencapian GDP

12 Amartya Sen, Development as Freedom,(New York : Oxford University Press, 1999) dan GNP), tetapi juga dengan memperhatikan indeks kemanusiaan dan keberlangsungan lingkungan. Manusia, objek yang menjadi sasaran utama program pembangunan, meiliki dimensi kehidupan yang sangat kompleks dan pembangunan seharusnya memperhatikan keseluruhan pencapaian dimensi tersebut yakni dimensi sosial, budaya, hukum dan politik.

Kesenjangan dan kemiskinan merupakan dampak dari tidak merasatanya distribusi hasil pembangunan secara fisik dan eknomis. Hal ini terjadi akibat dari praktek pembangunan yang mengabaikan dimensi moral dan etika. Kesenjangan tercipta karena penguasaan faktor-faktor produksi oleh segelintir orang dan sistem ekonomi liberal maupun neoliberal malah memperkuat penguasaan tersebut, sehingga masyarakat yang memiliki kemampuan kecil untuk akses sumber daya menjadi semakin miskin dan terkebelakang.

Berdasarkan penilian terhadap sejarah mengenai keberhasilan pembangunan di negara dunia ketiga, para pengkaji pembangunan telah 
memikirkan dan mempertimbangkan bahwa diperlukannya suatu konsep baru mengenai pembangunan, dimana konsep tersebut harus menyertai perencanaan dan praktek pemabangunan. Pembangunan harus mampu menyeimbangkan antara dimensi manusia sebagai individu, sosial, dan lingkungan. Dalam hal ini diperlukannya suatu tatanan nilai dan etika yang menyertai program pembangunan tersebut. Etika pembangunan dapat dikembangkan kepada etika pemerintah (good government), etika politik (the practices of good politic), etika bisnis (good corporated governance) yang kesemuanya akan berujung pada good governance dengan tiga pilarnya pemerintah, pelaku bisnis, dan masyarakat.

\section{Referensi}

Fakih, Mansour. Runtuhnya Teori Pembangunan dan Globalisasi. Yogyakarta : Pustaka Pelajar, 2002

Goulet, Denis. The Cruel Choice: A New Concept in the Theory of Development. New York: Athenaeum, 1971

Giri, Ananta Kumar dan Philip Quarles van Ufford. Kritik Moral
Pembangunan. Yogyakarta : Kanisius, 2004

Hadiz, Liza (ed). Ketimpangan: Masalah Lama Dengan Relevansi Baru Inequality: An Old Issue Of New Relevance. Diakses pada http://smeru.or.id/newslet/2005/ news16.pdf

Klien, Naomi. Shock Doctrine. diakses pada

http://www.naomiklein.org/sho ck-doctrine

Peet, Richard dan Elaine Hartwick. Theories of Development. New York : The Guilford Press, 2009

Szirmai, Adam. The Dynamics of Socio-Economic Development; an Introduction. Cambridge : Cambridge University Press, 2005.

Sen, Amartya. Development as Freedom.New York : Oxford University Press, 1999

Subhillar. Etika Pembangunan : Kajian Alternatif dalam Studi Pembangunan. diakses pada http//www.usu.ac.id/id/files/pid ato/ppgb/2008/ppgb_2008_sub hilhar.pdf, 22 Januari $201 \overline{0}$

Torado, Michael P. Pembangunan Ekonomi Di Dunia Ketiga. Edisi Keenam. Terj. Haris Munandar. Jakarta : Erlangga, 1998

Winarno, Budi. Pertarungan Negara vs Pasar. Yogyakarta : Media Pressindo, 2009 